\title{
New Media and Technological Transformation
}

\author{
Tugay Arat \\ Akdeniz University, Professor, Faculty of Communication, Turkey
}

\section{Abstract}

The new media, which emerged with the effect of technological developments, brought a new dimension to communication. Technology product applications transcend the borders of traditional media and become an actor on a global scale. Thanks to new media applications, products such as information, news, and cinema are rapidly spreading from the country of manufacture to the whole world. Undoubtedly, it is very important that the internet has been improved in these developments. Internet has increased the relationship of many tools with each other. For example, it has caused radical changes in the general structure of the television or mobile phone, which is a great entertainment tool. With the constant change pointed out by the new media, the television left the living room, became accessible everywhere, and the TV viewers turned into individual users. Now, mobile phones, televisions with internet, tablets are important tools for viewers to reach rich content. Today, the demand for new media has made it necessary to transform its content too. As the importance of the content increases day by day; Over the air platforms such as Netflix and Blu TV have emerged. These digital platforms have also changed the movie watching habits of the audience. In addition to the ease of use that new media offers, it also changes the way you watch television or movies. Viewers can access digital platforms whenever and wherever they want.

The aim of this study is to examine the transformation of the developments in communication technologies in the television and cinema watching habits of the audience. The survey method was used as a data collection tool to determine the new media usage habits of the audience. The universe of the research is students of Akdeniz University Communication Faculty. The sample of the study is 90 students of Akdeniz University Faculty of Communication. The survey was conducted online with the link sent to their WhatsApp. SPSS statistics program was used to analyze the data.

Keywords: New media, new media technologies, transformation of television and movie watching practices

\section{Introduction}

The communication process, which has been continuing non-stop since the first periods of human history, has gone through many transformations. Information and communication technologies are developing in a dizzying way today. In this way, access to information is facilitated more easily, and interpersonal communication and mass communication are provided more easily. The functions of the media, which continued with traditional mass media such as television, radio and newspapers until recently, have gained very different expansions thanks to the developments in communication, telecommunication and computer technologies. Internet and computer technology has created the term "new media" by transforming the media into an important communication tool and place. Nowadays, new media technologies such as computers, smartphones and tablets have enabled the digitization of media. With digitization, newspapers, movies, television and radio broadcasts have been transferred to the digital environment via the internet. This situation has caused major transformations in the production, distribution and display processes, which are the basic applications of the media.

Thanks to digitization, changes have occurred in radio content production and transmission of broadcasts. Broadcasting service over the Internet has facilitated access to radio. However, new types of services such as online music playlists and cloud music services have reduced the need for radio. In the digitalization process, radio is in a new search for its own future.

Television is an important part of our daily life. Television is "one of us" from seven to seventy in all areas such as news, entertainment and education. Nowadays, with the effect of technology, important transformations are taking place in the television watching culture. Services such as IPTV and Web TV have started to provide video and television services.

In addition, digitization has positively affected the film production process such as sound, editing, effects, screening, and distribution over the internet. The cinema industry and the film industry have been particularly influenced by technological innovations since its inception. Internet-based platforms have emerged that offer movies and series. The biggest of these is Netflix. Netflix; Today, it offers content such as TV series, movies and documentaries to over 140 million subscribers in 190 countries. This success of Netflix has inspired the establishment of similar domestic platforms in many countries.

Especially in the last two decades, thanks to internet technology, new media has been transformed to a great extent. Efforts of digital transformation, which affects all media, to provide different services to the masses have been increasingly encountered in recent years.

This study reveals the changes brought about by the digital transformation in the television and cinema viewing habits of the audience. The universe of the study is students of Akdeniz University Communication Faculty. 55 students representing the universe constitute the sample of the study. The questionnaire was applied online by sending a link to the students. The survey reveals in detail the television, TV series and movie watching behaviors of the students. Accordingly, most of the students have adopted the digitalized new media. It has been found that students hardly ever use traditional media. 


\section{Traditional Media}

Traditional media are communication tools that were used in the pre-internet period and still continue to be used today. It is possible to group these into written publications such as newspapers, magazines, and radio and television. These tools are one-way and the flow of news is from one side to the many. It is not possible for the reader, listener or viewer to transmit their views and reactions instantly, except to participate in the live broadcast over the phone. In the print media, a reader's opinion and suggestion could be conveyed by mail, which required a long process (Dedeoglu, 2016: 34). Today, news, text, sound, video, graphics, animation and 360-degree opportunities can be used in written publications. These possibilities enable journalists to tell their stories in the most appropriate way, without being restricted by the limited methods found in old analog media (Pavlik, 2013: 11). In addition, today's technology plays an important role in the news gathering and news production process. Now, there are various techniques to obtain raw data such as recording the news on a video, recording the conversation on the phone, as well as taking notes on a piece of paper (Pavlik, 2013: 77).

Radio, which is a traditional medium, transmits an audible message through electromagnetic radio frequency waves (Aziz, 1976: 6). Traditional terrestrial radio broadcasting tries to adapt to today's multi-media world, which is formed as a result of digital broadcasting and information communication technologies. Radio broadcasting transmits radio broadcasts over the internet channel using digital transmission techniques. Digital radios broadcasting over the Internet broadcast in different formats without the difficulty of finding frequencies, and can reach their audience through smartphones with internet access (Yilmaz, 2020: 33). Before we explain the new media, we need to understand the non-new, traditional media. Everything in traditional media is based on monologue. Someone would get up and say something, and anyone possible would listen. But who were the audience, what were their ages, genders, what did they think about the story? There was no real way to find out about them. It is at this point that new media diverges from traditional media, so new media are media that are in dialogue with you. Someone tells something, everyone listens, and then everyone comments, likes, criticizes, shares, suggests about it. Moreover, a lot of information is obtained about the people who do these and who can answer when asked (Bulunmaz, 2014: 25).

\section{New Media}

The emergence of new media technologies has been made possible by the combination of historical developments in computer and media technologies that progress in two different ways. Mass media and information processing are technologies that complement each other, they have emerged and developed together (Baslar, 2013: 775). The process of laying the foundations of television and reaching digital broadcasting is called analog technology. In analog technology, after the signals are received by the roof antennas, the signal amplifier device is activated. After the signals are sufficiently strong, the television detects those signals and turns them into sound and image (Ak, 2013: 12).

Broadly speaking, the term new media covers "the entire computing domain, computer technologies and related data content. Digital technology is a through communication. The technological nature of new media is based on the digital (digital) encoding and data processing of these communication technologies. To record information (character, image, sound, action, description), digital technology uses digital coding, so digitization is the process of converting information into a digital code. All information is digitized with a binary system, one and zero, so the contents are encoded numerically (Hauer, 2017: 2).

Digital technology, which forms the basis of digital broadcasting, translates data in the form of sound, music, text and images into computer language with the help of microprocessors (Bagci, 2016: 4). Rapid developments in digital technologies have accelerated the transition from analog systems to digitalization in many areas. The terrestrial digital broadcasting system is the adaptation of the analog broadcasting system to television within the framework of this development process. In other words, it enables digital broadcasts to be received with the help of satellite and cable. In this way, it provides much more television broadcasts from the existing image and sound quality than the existing television broadcasts in the analog broadcasting system at higher standards (Karaca, Birgor, 2007: 21). Television broadcasting in Turkey it has been in a constant process of change as well as in the world. Later, the internet started the transition to the age of communication, which had previously progressed within the framework of military purposes. Experiencing great changes in the development process of the Internet in a short time has made it a technology that can be found in every moment of life (Dikmen, 2017: 1).

The three main features of New Media are as follows;

- Interaction: The presence of interaction is required in the communication process. In this way, both the receiver and the transmitter are affected by each other.

- Demassification: It can be decentralizing enough to allow private messages to be exchanged with each individual within a large user group. In this way, different messages can be sent to everyone.

- Asynchronous: New communication technologies enable the individual to send or receive messages whenever they want. It eliminates the need for simultaneousness (Geray, 2003: 18).

The installation and running costs of new media are almost nonexistent compared to traditional media, which is making the opportunity to become an entrepreneur almost everyone. New media has created brand new business opportunities for entrepreneurs who are thinking of making money by starting a business. In the formation of these advantages, there is the feature of 
being interactive, which has become an indispensable condition for new media (Sahin, 2016: 53).

While previously the notion of "media" referred to a handful of mass communication tools such as newspapers, radio, television, and film, the current academic conception of media is broader, reflecting the proliferation of new communication technologies in recent times. Media today range from a plethora of devices (smart phones, robots) to channels (Internet, cable) to venues on those channels (social networking sites, home shopping network) and / or devices (smartphone apps).

'New media' is a historically relative term, and it has been used to define a range of different applications and communication technologies since the 1960s (Marvin, 1988). Today, 'new media' has been defined as communication technologies that enable or facilitate user-to-user interactivity and interactivity between users and information, and the main point in the definition is that the one-to-many model of traditional mass communication is challenged by the possibility of many-to-many communication via the Internet.

When the developments on television in the media are considered; It has created changes in the usage of television and internet. Displaying the broadcasts over the Internet in television broadcasting systems using the Internet has enabled real-time viewing. In addition, Internet TV, which has the feature of providing transition between videos, provides additional information and interaction about these videos (Uluoglakci, 2011: 57). Thanks to interactive television broadcasting, the change of the television industry has also been observed, thanks to the freedom of the audience to watch sound, image and data on demand. IPTV is one of the most effective technological developments of this change (Tasdelen and Kesim, 2014: 269). Today, IPTV technology is happening by connecting the wi-fi enabled television to the wireless network.

Durmaz (2004: 4-6) summarizes the technical features and advantages of digital television broadcasting compared to analog broadcasting as follows; Digital television broadcasting provides better quality sound and image. The channel capacity carried by satellite and cable broadcasts has increased. While the adverse effects of weather conditions are very high in analog broadcasts, there is no negativity in digital broadcast technology and quality communication can be provided. In digital broadcasting, digitally coded images and sounds are compatible with all existing transmission networks (cable TV, satellite and terrestrial broadcasting). Digital broadcasting can be used for radio and television broadcasting in internet and similar communication standards (IPTV, Mobile TV). In digital television broadcasting, viewers can be given additional information, apart from the image, on demand. (News, weather and road condition, subtitle). In digital television broadcasting, movies can be broadcast in more than 2 languages on demand. In digital broadcasting, the audience can choose the program they want. Digital broadcasting allows for different screen formats (4: 3,16: 9,14: 9). Digital broadcasting ceases television from being a passive viewing tool and involves the audience in every aspect. Thus, a communication and interaction environment are formed (Durmaz 2004: 4-6). The definition that is mostly thought of when talking about new media; the internet. The internet is the place where the convenience and speed of accessing information that comes with internet technology, different communication ways and social networking networks have acquired in our lives. But the new media should have a broader explanation, including this definition. The first statement about the new media is more about the distribution of information, but the user can also be active in the new media. To make a definition, new media are new technologies and their use, as well as new methods developed for old technologies. As an example of these new methods; e-books, internet newspapers, digitally produced animation and 3D films can be given (Bulunmaz, 2014: 25).

With the active proliferation of websites on the Internet, the main goal is personal entertainment. Accessing information and downloading files are at the forefront in personal entertainment. In Web 2.0, this situation leaves its place to personal publishing. Users can update and create new content as part of the content. Web 3.0 works completely online and is based on the semantic interrelationship of the data in the digital environment. With the internet; There is a restructuring of time and space (Yengin, 2015: 49).

\begin{tabular}{l|l|l|l|}
\hline & Web $\mathbf{1 . 0}$ & Web $\mathbf{2 . 0}$ & Web $\mathbf{3 . 0}$ \\
\hline Communication & Broadcasting & Interactive & Online \\
\hline Information & Static (read only) & Dynamic & Portable and personal \\
\hline Target & Institution & Community & Personal \\
\hline Usage & Personal Web Pages & Blogs / Wiki & File streams \\
\hline Produce & Entertainment & Broadcasting & Creativity \\
\hline Interaction & Web Formats & Web Applications & Smart Applications \\
\hline Scanning & Directories & Keywords & Context-Relevance \\
\hline Advertisement & Stable & Interactive & Personal \\
\hline Research & Britannica Online & Wikipedia & Semantic Web \\
\hline Technology & Html/Ftp & Flash/Java/Xml & Rdf/Rdfs/Owl \\
\hline
\end{tabular}

Table 1. Web 1.0, Web 2.0 and Web 3.0 (Source: Yengin, 2015: 49). 


\section{Method}

This study, which is a qualitative research, has a descriptive and explanatory structure. It is the subject of the study to reveal the television, TV series and movie watching behaviors of the students in detail. The universe of this study is Akdeniz University Faculty of Communication students, which is approximately 900 people. Because the universe is very large, 90 samples were taken from the universe using the Easy Sampling method. The research was restricted to Akdeniz University Faculty of Communication students only. It is important to learn about the new media viewing behavior of young people. Questionnaire technique was used to collect and analyze data in the research. 2 demographic questions were used in the questionnaire and 17 questions were used in 15 to get audience behavior. The questions were prepared by the researcher, their validity was ensured and their reliability was tested. The survey was prepared with Google Forms for students in February 2021 and applied by sending a link to the students' departments via WhatsApp. SPSS 20.0 statistics program was used to analyze the obtained data.

\section{Findings}

\begin{tabular}{|c|c|}
\hline & Cronbach Alfa Reliability Coefficient \\
\hline 19 Items & 0,68 \\
\hline
\end{tabular}

Table 2. Reliability Coefficients

The expert validity of the questionnaire was provided. In addition, Cronbach's Alpha value was calculated for the reliability of the questionnaire. Cronbach's Alpha $=0.65$. This value reveals that the survey is reliable.

\begin{tabular}{|l|c|c|}
\hline & Frequency & Percent \\
\hline Woman & 61 & 67,8 \\
\hline Man & 29 & 32,2 \\
\hline & $\mathbf{9 0}$ & $\mathbf{1 0 0 , 0}$ \\
\hline
\end{tabular}

Table 3. Gender

$67.8 \%$ of the students participating in the study with easy sampling method are women and $32.2 \%$ are men.

\begin{tabular}{|l|c|c|}
\hline & Frequency & Percent \\
\hline $\begin{array}{l}\text { Radio Television and } \\
\text { Cinema }\end{array}$ & 10 & 11,1 \\
\hline Journalism & 37 & 41,1 \\
\hline $\begin{array}{l}\text { Public Relations and } \\
\text { Publicity }\end{array}$ & 24 & 26,7 \\
\hline Advertising & 19 & 21,1 \\
\hline Total & $\mathbf{9 0}$ & $\mathbf{1 0 0 , 0}$ \\
\hline
\end{tabular}

Table 4. Departments of the Students Participating in the Study
The sections of the students participating in the study are shown in Table $4.11 .1 \%$ of the students are from Journalism, $34.8 \%$ from Public Relations, 26.7\% from Radio Television and Cinema, and 21.1\% from Advertising.

\begin{tabular}{|l|c|c|}
\hline & Frequency & Percent \\
\hline Traditional TV & 11 & 12,2 \\
\hline Internet TV & 79 & 87,8 \\
\hline & $\mathbf{9 0}$ & $\mathbf{1 0 0 , 0}$ \\
\hline
\end{tabular}

Table 5. Individual Television Watching Source

Only $87.8 \%$ of the students watch television on the internet. The rate of those who watch television on TV is $12.2 \%$. Thanks to the developing communication technologies, online broadcasting on the internet has become the preference of individual viewers especially.

\begin{tabular}{|l|c|c|}
\hline & Frequency & Percent \\
\hline Yes & 18 & 20,0 \\
\hline No & 72 & 80,0 \\
\hline & $\mathbf{9 0}$ & $\mathbf{1 0 0 , 0}$ \\
\hline
\end{tabular}

Table 6. Status of Watching the Programs on the Broadcast Day and Time

Only $20 \%$ of the students watch the television programs on the day and hour, and $80 \%$ watch the programs from the archive of the programs on the internet.

\begin{tabular}{|l|c|c|}
\hline & Frequency & Percent \\
\hline Smart Phone & 39 & 43,3 \\
\hline Tablet & 2 & 2,2 \\
\hline Laptop & 41 & 45,6 \\
\hline Desktop & 4 & 4,4 \\
\hline $\begin{array}{l}\text { Television } \\
\text { (with Internet) }\end{array}$ & 4 & 4,4 \\
\hline Total & $\mathbf{9 0}$ & $\mathbf{1 0 0 , 0}$ \\
\hline
\end{tabular}

Table 7. Digital Tool Used While Watching Internet Broadcasting

It is seen in table 6 that students mostly use their laptop computers (45.6\%) while watching television via internet technology, and secondly, they use their smart phones $(43.3 \%)$. It is observed that students do not prefer to use desktop computers $(4.4 \%)$, tablets $(2.2 \%)$ and internet-based televisions (4.4\%). 


\begin{tabular}{|c|c|c|}
\hline & Frequency & Percent \\
\hline Yes & 67 & 74,4 \\
\hline No & 23 & 25,6 \\
\hline & 90 & 100,0 \\
\hline
\end{tabular}

Table 8. Television Program Watching Status on Social Media

Table 8 shows the television watching habits of the students participating in the study. Accordingly, $74 \%$ of the students watch the programs on social media, while $25.6 \%$ do not watch the programs on social media.

\begin{tabular}{|l|c|c|}
\hline & Frequency & Percent \\
\hline Yes & 45 & 50,0 \\
\hline No & 45 & 50,0 \\
\hline & $\mathbf{9 0}$ & $\mathbf{1 0 0 , 0}$ \\
\hline
\end{tabular}

Table 9. Television Program Watching Status on Internet TV Series Websites

Considering the habits of students to watch television programs on TV series platforms on the Internet, it is divided into two. While $50 \%$ of the students watch TV shows, $50 \%$ of them do not use these sites.

\begin{tabular}{|l|c|c|}
\hline & Frequency & Percent \\
\hline Yes & 79 & 87,8 \\
\hline No & 11 & 12,2 \\
\hline & $\mathbf{9 0}$ & $\mathbf{1 0 0 , 0}$ \\
\hline
\end{tabular}

Table 10. The Situation of the New Media to Liberate the Person

Table 10 shows the views of the students participating in the study about the feeling of being freer to watch television programs on the new media. Accordingly, $87.8 \%$ of the students think that the new media frees them. $12.2 \%$ of them do not agree with this opinion.

\begin{tabular}{|l|c|c|}
\hline & Frequency & Percent \\
\hline At the cinema & 3 & 3,3 \\
\hline On Television & 3 & 3,3 \\
\hline On Internet & 18 & 20,0 \\
\hline $\begin{array}{l}\text { Digital platforms } \\
\text { (Netflix etc.) }\end{array}$ & 62 & 68,9 \\
\hline On their smart phones & 4 & 4,4 \\
\hline Total & 90 & $\mathbf{1 0 0 , 0}$ \\
\hline
\end{tabular}

Table 11. Platform Used to Watch Movies
Most of the students participating in the study $(68.9 \%)$ firstly use digital platforms to watch movies and secondly the internet $(20.0 \%)$. The very low rate of watching the movie in the cinema can be explained by the fact that the cinemas were closed due to the Covid 19 virus at the time of the research. However, it is a fact that with the digitalization, the way of watching movies has also changed. Students especially use platforms such as Netflix, Blu Tv, TVbu, YouTube.

\begin{tabular}{|l|c|c|}
\hline & \multicolumn{1}{|c|}{$\begin{array}{c}\text { Std } \\
\text { Deviation }\end{array}$} & Mean \\
\hline $\begin{array}{l}\text { Watching Movies } \\
\text { Without Ads }\end{array}$ & 0,81963 & 4,4111 \\
\hline $\begin{array}{l}\text { Continuing the Movie, } \\
\text { I Watch from Where } \\
\text { I Left }\end{array}$ & 0,81871 & 4,3222 \\
\hline $\begin{array}{l}\text { Watching Movies with } \\
\text { High Image Quality }\end{array}$ & 0,77741 & 4,1889 \\
\hline \begin{tabular}{l} 
Domestic or Foreign \\
\hline
\end{tabular} & 1,16310 & 3,1333 \\
\hline
\end{tabular}

Table 12. The Most Important Elements When Watching Movies

The students were asked how important the elements in Table 12 were while watching a movie. According to this, "watching movies without advertisements" was seen as the first important factor, secondly "to be able to continue the movie from where you left off", thirdly "to watch movies with high image quality", and fourthly "to be domestic or foreign" was seen as an important factor. Accordingly, students want to watch movies and series without advertising, to be able to continue the movie where they left off, and to watch movies with high image quality. It seems difficult for students who have acquired these habits to return to traditional tools.

\begin{tabular}{|l|c|c|}
\hline & Frequency & Percent \\
\hline Netflix & 51 & 56,6 \\
\hline Amazon TV & 12 & 13,3 \\
\hline Tv+ & 11 & 12,3 \\
\hline Puhu TV & 8 & 8,9 \\
\hline Tivibu & 8 & 8,9 \\
\hline Total & $\mathbf{9 0}$ & $\mathbf{1 0 0 , 0}$ \\
\hline
\end{tabular}

Table 13. Membership to Digital Platforms

Students are members of multiple digital platforms. There are students with two and three members. The most subscribed platforms are Netflix, Amazon TV, TV + , Puhu TV, Tivibu, respectively. Netflix seems to be the leader among these platforms. 


\begin{tabular}{|l|c|c|}
\hline $\begin{array}{l}\text { To be able to watch } \\
\text { the movies I missed at } \\
\text { the cinema }\end{array}$ & Frequency & Percent \\
\hline $\begin{array}{l}\text { Because it is cheaper } \\
\text { Due to the opportunity }\end{array}$ & 7 & 1,1 \\
\hline $\begin{array}{l}\text { to watch whenever } \\
\text { I want }\end{array}$ & 45 & 50,0 \\
\hline $\begin{array}{l}\text { Because I can watch } \\
\text { from the comfort of my } \\
\text { home and effortlessly }\end{array}$ & 35 & 38,9 \\
\hline $\begin{array}{l}\text { Due to the ability to } \\
\text { comment and watch } \\
\text { with family and friends }\end{array}$ & 2 & 2,2 \\
\hline Total & $\mathbf{9 0}$ & $\mathbf{1 0 0 , 0}$ \\
\hline
\end{tabular}

Table 14. Reason for Subscribing to the Digital Platform Used

Table 14 shows the reasons for students to become a member of the digital platform used. Accordingly, the most important reason is that students have the opportunity to watch whenever they want. The second most important reason is that students can watch digital platforms effortlessly in a comfortable environment at home. Although not very important, the cheapness of digital platforms is one of the reasons. The students did not consider their judgments "To be able to watch the movies I missed in the cinema" and "Because of the opportunity to watch them by commenting with family and friends" as important reasons.

\begin{tabular}{|l|c|c|}
\hline & Frequency & Percent \\
\hline TV series & 53 & 58,9 \\
\hline Film & 32 & 35,6 \\
\hline Documentary & 4 & 4,4 \\
\hline Animation & 1 & 1,1 \\
\hline Total & $\mathbf{9 0}$ & $\mathbf{1 0 0 , 0}$ \\
\hline
\end{tabular}

Table 15. Most Watched Type of Digital Platform Used

In the digital platform used by the students participating in the study, the most TV series $(58.9 \%)$, secondly film (35.6\%), thirdly documentary $(4.4 \%)$ and fourthly animation $(1.1 \%)$ are watched. It is also seen from the results of the research that the recently shot TV series connect people to the screen.

\begin{tabular}{|l|c|c|}
\hline & Frequency & Percent \\
\hline A few times a week & 33 & 36,7 \\
\hline Once a day & 31 & 34,4 \\
\hline Once a week & 13 & 14,4 \\
\hline A few times a month & 7 & 7,8 \\
\hline Once a month & 6 & 6,7 \\
\hline Total & $\mathbf{9 0}$ & $\mathbf{1 0 0 , 0}$ \\
\hline
\end{tabular}

Table 16. Frequency of Watching Movies or TV Series from Digital Platforms

The majority of the students participating in the study $(36.7 \%)$ watch movies or TV series several times a week. The rate of those who watch movies or TV series once a day is also high (34.4\%). $14 \%$ of the students participating in the research watch movies or TV series once a week, $7.8 \%$ several times a month, and $6.7 \%$ once a month. Accordingly, students use digital platforms extensively to watch movies or TV series.

\begin{tabular}{|l|l|l|c|c|c|}
\hline & N & Mean & Std.Devision & t & P \\
\hline Woman & 61 & 3,9672 &, 56730 & & \\
\hline Man & 28 & 4,1071 &, 51563 & $-1,111$ & 0,270 \\
\hline
\end{tabular}

Table 17. Important Elements While Watching Movies According to Gender

Independent Samples t-test analysis was performed to determine whether the important factors while watching the movie differ according to gender. Accordingly, there is no difference between gender and the attitudes attached importance to watching movies.

\begin{tabular}{|l|c|c|c|c|c|}
\hline & Sum of Squares & df & Mean Square & F & Sig. \\
\hline Between Groups & 1,438 & 3 &, 479 & 1,618 &, 191 \\
\hline Within Groups & 25,482 & 86 &, 296 & & \\
\hline Total & $\mathbf{2 6 , 9 2 0}$ & $\mathbf{8 9}$ & & \\
\hline
\end{tabular}

Table 18: Important Elements While Watching Movies According to Departments 
One Way Anova test was applied to determine whether there is a differentiation according to the elements they care about while watching movies according to the departments of the students participating in the study. No significant differentiation was found in the test result. All department students think the same way.

\section{Conclusion}

Now, mobile devices such as smartphones and tablets have entered our lives. Thanks to these tools, all the services offered by traditional vehicles are gathered within these portable vehicles thanks to the internet. These tools have revealed the change from collective monitoring to individual monitoring, and with these devices, the user-viewer actively participates in the process. It is seen that traditional mass media, which are actively involved in the daily life of individuals, are disappearing day by day. Because the limitations in their content, the way they are presented, the time and place dependence features cannot compete with the new media. The new media layout is open, web-based, unlimited, interactive. In this way, it provides convenience to people in almost every field. Thanks to technological development, it is seen that new media is effective in the structure of society. A great majority of the Faculty of Communication students participating in the study think that the new media frees them.

According to the results of this research, which is applied on the students of Akdeniz University Faculty of Communication, Journalism, Public Relations, Radio, Television, Cinema and Advertising Department; Most of the students watch television on the internet. Online publishing has now become the choice of individual viewers. Most of the students do not watch the programs on their day and time, then they watch the programs from their archives on the internet. Students mostly use laptops and smartphones while watching internet broadcasting. They hardly use desktop computers, tablets and internet-based televisions. It is also common for broadcasts to be watched on social media. Three quarters of the students follow publications on social media. Half of the students watch their television programs on TV serial platforms. Almost all students are members of a digital platform that offers film series. Students mostly watch TV series, secondly, and the rate of watching documentaries and animated documentaries is very low. According to the students participating in the research, the new media frees the students. Most of the students firstly use digital platforms to watch movies, and secondly, the internet is used. Watching behavior in cinema and television is extremely low. According to the students, the most important reasons for the high usage rates of digital platforms are as follows; Watching movies without ads, to be able to continue the movie where they left off, to watch movies with high image quality. In addition, it was determined that there was a transition from collective monitoring to individual monitoring. In a very short period of time, general habits have changed, and the view of young people towards mass media such as newspapers, magazines, television, cinema and radio, which we define as traditional media, has shifted to a different dimension. Now, young people have abandoned habits in mass communication. This situation has brought about a great change. It is a matter of curiosity how new developments will affect viewing habits in the future.

\section{Bibliography}

Ak, M. 2013. Televizyon Yayıncılığındaki Gelişmeler ve Etkileşimli Televizyon Yayıncılığı. (Yüksek Lisans Tezi). İstanbul: Marmara Üniversitesi Sosyal Bilimler Enstitüsü.

Aziz, Aysel 1976. Radyo ve Televizyona Giriş. Ankara: Ankara Üniversitesi Siyasal Bilgiler Fakültesi.

Bağcı, C. 2016. Türkiye'de Sayısal Televizyon Yayıncılığının Sektörel Görünümü ve Yönelimleri. (Yüksek Lisans Tezi). Kayseri: Erciyes Üniversitesi Sosyal Bilimler Enstitüsü.

Başlar Gülşah 2013. Yeni Medyanın Gelişimi ve Dijitalleşen Kapitalizm, Akademik Bilişim 2013 - XV. Akademik Bilişim Konferansı Bildirileri.

Bulunmaz Barış 2014. Yeni Medya Eski Medyaya Karşı: Savaşı Kim Kazandı Ya Da Kim Kazanacak, Karadeniz Teknik Üniversitesi IIletişim Araştırmaları Dergisi, Volume 4, Issue 1.

Dedeoğlu Gözde 2016. Teknoloji, Iletişim, Yeni Medya ve Etik, Sentez Yayın Dağıtım.

Dikmen, E., Ş. 2017. "Türkiye'de Televizyon Yayıncılığının Dönüşümü: Sosyal Tv Yayıncılığı”. Gümüşhane Üniversitesi Iletişim Fakültesi Elektronik Dergisi. 5 (1). 425-448.

Durmaz, Ahmet 2004. Dijital Televizyonun Temelleri, Eskişehir: Anadolu Üniversitesi Yayınları, 1.Baskı.

Enli Gunn 2017. New Media and Politics, Annals of the International Communication Association, Volume 41, Issue 3-4.

Geray, Haluk 2003. İletişim ve Teknoloji Uluslararası Birikim Düzeninde Yeni Medya Politikaları. Ankara: Ütopya.

Hauer Thomas 2017. Technological determinism and new media, International Journal of English, Literature and Social Science, Vol-2, Issue-2.

Karaca, Ü., Birgör, U. (2007). "Karasal Sayısal Yayın". Ege Bölgesi Enerji Forumu. İzmir: TMMOB Elektrik Mühendisleri Odası.

S. Shyam Sundar and Anthony M. Limperos 2013. Uses and Grats 2.0: New Gratifications for New Media, Journal of Broadcasting \& Electronic Media, Volume 57, Issue 4.

Sahin M. 2016. Geleneksel Medyanın Yeni Rakibi: Yeni Medya ve Canlı Yayınlar, Yeni Medya Hakemli, Akademik, E-Dergi, Sayı: 1.

Pavlik V. John 2013. Yeni Medya ve Gazetecilik, (Çev: Müge Demir, Berrin Kalsın), Phoenix Yayınevi.

Taşdelen, B., Kesim, M. 2014. "Etkileşimli Televizyon Geleneksel Televizyona Karşı: Televizyon İzleyicisi $\mathrm{Ne}$ İster?". Selçuk İletişim Dergisi, Cilt 8, Sayı 4, 268-280.

Uluoğlakçı, C. 2011. Medya Ekonomisinden İş Modeline: Yeni Yayıncılık Teknolojileri, (Uzmanlık Tezi), Ankara: Radyo Televizyon Üst Kurulu.

Yengin Deniz 2015. Yeni Medyanın Olanakları: Semantik Web, The Turkish Online Journal of Design, Art and Communication TOJDAC January 2015 Volume 5 Issue 1.

Yılmaz Alper 2020. Radyo ve Sosyal Medya Yakınsaması: TRT Radyo ve TRT FM'in Facebook ve Twitter Pratikleri, TRT akademi Dergisi, Cilt 5 Sayı 9. 